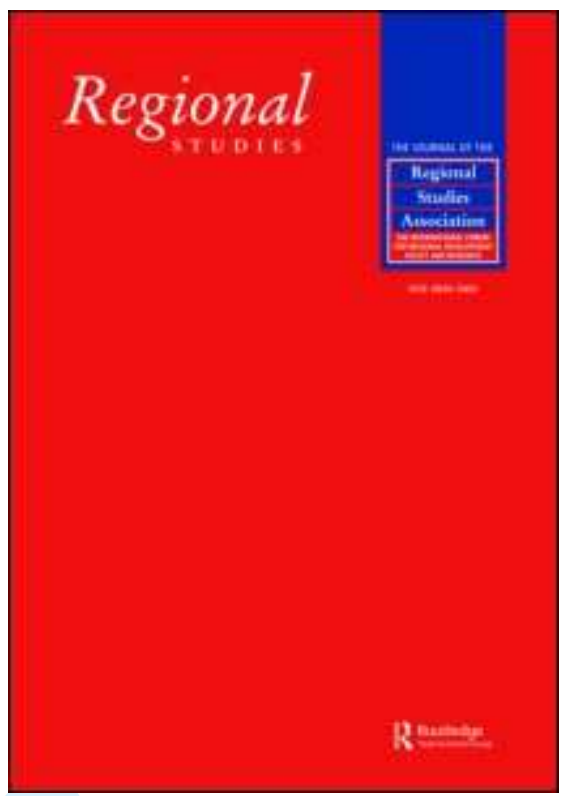

\title{
New Business Formation by Industry over Space and Time: A Multi-Dimensional Analysis
}

\begin{tabular}{|r|l|}
\hline Journal: & Regional Studies \\
\hline Manuscript ID: & CRES-2005-0012.R2 \\
\hline Manuscript Type: & Main Section \\
\hline JEL codes: & $\begin{array}{l}\text { D21 - Firm Behavior < D2 - Production and Organizations < D - } \\
\text { M R - Urban, Rural, and Regional Economics, L10 - General < L1 - } \\
\text { Market Structure, Firm Strategy, and Market Performance }<\mathrm{L}- \\
\text { Industrial Organization }\end{array}$ \\
\hline Keywords: & $\begin{array}{l}\text { regional economics, New business formation, industrial economics, } \\
\text { entrepreneurship }\end{array}$ \\
\hline
\end{tabular}

\section{SCHOLARONE" Manuscripts}




\section{New Business Formation by Industry over Space and Time: A Multidimensional Analysis}

\author{
MICHAEL FRITSCH $^{+}$and OLIVER FALCK ${ }^{++}$ \\ February 2006
}

\begin{abstract}
We apply a multidimensional approach to simultaneously analyze the effects of three groups of determinants on new business formation: industry, space, and changes over time. The data are for West Germany and covers the period from 1983 to 1997 . Our analysis indicates that the positive impact of small business employment found in many previous studies may be mainly explained by minimum efficient size in the respective industry. Moreover, innovation activities and the technological regime play an important role in new business formation processes. There are some differences with regard to the impact of a number of variables on start-ups in the manufacturing and the service sector. While a high level of short-term unemployment has a positive impact on the number of startups in the service sector, no significant impact for long-term unemployment could be found.

JEL classification: $\quad$ D21, L10, R10
\end{abstract}

Keywords: $\quad$ New business formation, industrial economics, regional economics, entrepreneurship.

${ }^{+}$Corresponding author. Technical University Bergakademie Freiberg, Faculty of Economics and Business Administration, Lessingstr. 45, 09596 Freiberg (Germany), Telephone: ++49 (3731) 3924 39, Fax: ++49 (3731) 393690 , michael.fritsch@tu-freiberg.de

${ }^{++}$University of Passau, Faculty of Economics and Business Administration, Innstraße 27, 94032 Passau (Germany), Telephone: ++49 (851) 50925 43, Fax: ++49(0851)50925 42, oliver.falck@uni.passau.de
Formatted: Line spacing: single

\section{Deleted: $\mathbb{T}$}

${ }^{+}$Corresponding author. Technical University Bergakademie Freiberg,

Faculty of Economics and Business

Administration, Lessingstr. 45, 09596

Freiberg (Germany), Telephone: ++49

(3731) 3924 39, Fax: ++49 (3731) 3936 90, II

michael.fritsch@tu-freiberg.ded

${ }^{++}$University of Passau, Faculty of Economics and Business Administration, Innstraße 27, 94032 Passau (Germany),

Telephone: ++49 (851) 5092543 , Fax: ++49 (0851) 5092542

oliver.falck@uni.passau.de

II

Deleted: December

Deleted: 5

Deleted: location 


\section{II}

Wir analysieren das Gründungsgeschehen mit einem mehrdimensionalen Ansatz, der simultan den Einfluss dreier Gruppen von Einflußfaktoren berücksichtig:

Branchenzugehörigkeit, Region und Änderungen über die Zeit. Die Daten beziehen sich auf Westdeutschland und decken den Zeitraum, 1983 bis $1997 \mathrm{ab}$. Unsere Untersuchung zeigt, dass der positive Einfluss von Beschäftigung im kleinbetrieblichen Sektor auf das Gründungsgeschehen, der in vielen früheren $\underline{\text { Studien festgestellt wurde, vor allem auf die Bedeutung der mindestoptimalen }}$ Betriebsgröße in der jeweiligen Branche zurückgeführt werden kann. Darüber hinaus stellen wir fest, dass den regionalen Innovationsaktivitäten und dem.

\section{Charakter des technologischen Regimes eine wichtige Rolle für}

Gründungsaktivitäten zukommt. Es zeigen sich einige Unterschiede hinsichtlich

Formatted: German (Germany) des Einflusses von Variablen auf die Gründungen im Industrie- und

Dienstleistungssektor. Während ein hohes Niveau an Kurzzeit-Arbeitslosigkeit einen positiven Effekt auf die Anzahl der Gründungen im Dienstleistungssektor $\underline{\text { hat, kann für die Langzeit-Arbeitslosigkeit kein signifikanter Einfluss festgestellt }}$ werden.

Formatted: German (Germany)

Schlagworte: Betriebsgründungen, Industrieökonomik, Regionalökonomik, Entrepreneurship. 


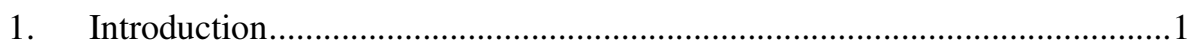

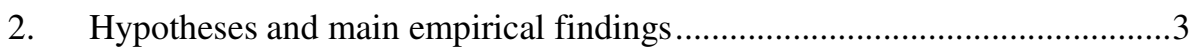

3. Overview of new business formation in Germany from 1983 to 1997 .........7

4. Variation of new business formation over industry, space, and time ............9

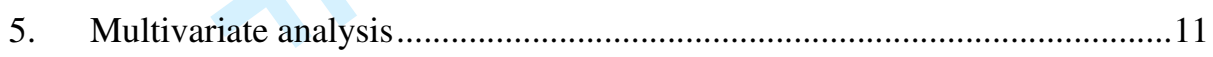

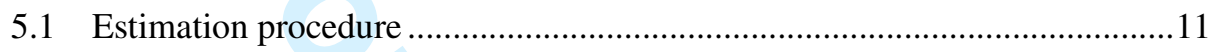

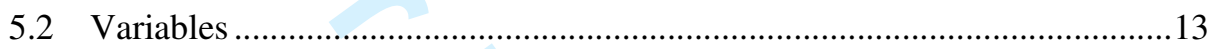

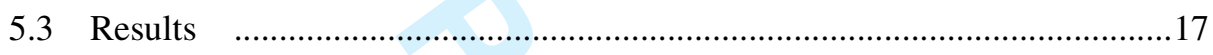

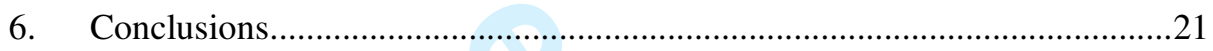

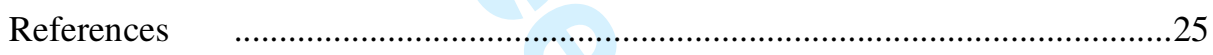

$\begin{array}{ll}\text { Tables and Figures } & 31\end{array}$

NOTES

Deleted: 41 


\section{Introduction*}

There is little doubt that new business formation plays an important role in the process of economic development (FRITSCH and MUELLER, 2004; VAN STEL and Storey, 2004; CARREE and THURIK, 2003). ${ }^{1}$ Each new business or market entry represents a challenge to the incumbents and, consequently, may generate significant incentives for improvements. The determinants of new business formation have been investigated theoretically and empirically in a number of ways Most empirical studies in this field are cross-sectional analyses of different Deleted: ${ }^{2}$ industries or regions. ${ }^{3}$ Longitudinal analyses of new business formation processes are rather rare. ${ }^{4}$ A severe shortcoming of these analyses is that most of them are limited to only one category of influence - industry, space or time - and tend to neglect other factors. The types of influences that are accounted for is mainly due to the approach chosen. For example, cross-sectional analyses limited to the industry level can only investigate the role of industry characteristics (e.g., minimum efficient size, capital intensity) but not regional determinants such as population density or workforce qualifications. Without accounting for the regional dimension, however, in the case of such industry-level studies, reliable results cannot be attained if the importance of a certain factor, such as innovation conditions, varies significantly across regions. Additionally, if certain regional conditions stimulate new business formation in some industries but deter start-ups in other industries, the effect of space on the formation of new businesses cannot be adequately assessed by means of an interregional approach that does not account for different industries. ${ }^{5}$ Moreover, empirical analyses should include multiple years to control for the possibility that the effect of the different determinants changes over time, and, more particularly, to account for the impact 
of factors that mainly have an influence on the macro or the national level, such as variation of wages, capital user cost, and overall demand.

As far as we know, such a comprehensive approach which simultaneously analyzes the influence of industry, space, and time on new business formation processes has not yet been conducted, presumably because of limitations in the available data. The available time-series are rather short, differentiation by industry is often rudimentary, and there are hardly any data supporting meaningful spatial categories. This shortcoming may be the cause of the mixed and partly contradictory results that have been found, particularly, in studies across industries (cf. EvANS and SIEGFRIED, 1994; GEROSKI, 1995). Based on a unique dataset, which was compiled from German Social Insurance Statistics (see FRITSCH and BRIXY, 2004, for details), we use a multidimensional approach to analyze the effects of the three groups of determinants - industry, space, and time - simultaneously. The data cover the period from 1983 to 1997 and provides information on the number of new businesses in each year within 52 private sector industries and 74 regions. The estimates enable us to assess the relative importance of the three types of determinants for new business formation processes. The results should be much more reliable than those found by analyzing only one or two categories of factors.

We begin with a brief outline of the main hypotheses and empirical findings about the determining factors in the decision to set up a business in a certain industry and region (section 2). This is followed by an overview of new business formation in West Germany during the period under review (section 3). Section 4 introduces the basic analytical approach and compares the variation of the number of start-ups over the three analytical dimensions: industry, space, and time. The 
analysis of relationships is reported in section 5. Finally, we draw some conclusions from the analysis, particularly with regard to the merits of the type of multi-level approach applied here (section 6).

\section{Hypotheses and main empirical findings}

In analyzing new business formation processes, we assume the perspective of a potential founder. According to this "labor market" approach (AUDRETSCH, 1995, pp. 47-50; STOREY, 1994, p. 60), every member of the workforce is faced with the question of whether to remain in dependent employment (or unemployment) or to start an own business. In this view, the start-up decision is determined by a person's subjective evaluation of the costs and benefits related to these alternatives. One group of factors that may be relevant for this decision is the personal characteristics of the potential entrepreneur. ${ }^{6}$ Other factors are characteristics of the industry and of the local environment.

In regard to the qualifications of the potential entrepreneur, many studies find a positive relationship between the education level and the propensity to start a business (BATES, 1990). However, work experience, particularly in the industry of start-ups, also seems to play an important role. A stylized fact of interregional analyses of new business formation is that the share of employment in small businesses is conducive to start-up activity (cf. REYNOLDS et al., 1994). The standard explanation for this result is that working in a small business stimulates the emergence of an entrepreneurial attitude; thus, increasing the likelihood that the businesses' employees will consider starting their own businesses (BEESLEY and HAMILTON, 1984; SORENSON and AUdia, 2000). This interpretation is based on the notion that smaller businesses have a less extensive internal division of 
labor than do larger businesses; hence, employees of these businesses are likely to gain exposure to a relatively big portion of the often tacit knowledge that is necessary in order to run a firm. This view is supported by evidence from empirical studies showing that many founders worked in small businesses before setting up their own enterprises (JOHNSON and CATHCART, 1979a and b; ARMington and ACS, 2002; WAGNER, 2004). ${ }^{7}$ Moreover, a high level of employment in small businesses in a region is probably associated with a relatively pronounced tradition of entrepreneurship; thereby increasing the confidence of potential entrepreneurs in their ability to open new ventures (SORENSON and AUDIA, 2000, p. 442f.). ${ }^{8}$ This is also the reason why these factors may be somewhat overestimated by the percentage of small business employment because it reflects, to some degree, the historical levels of regional entrepreneurship since most businesses begin small. The relevance of business size structure in a given region in relation to new business formation processes could result from the fact that most founders locate their businesses close to their homes (Johnson and CATHCART, 1979b; Mueller and MORGan, 1962; COOPER and DUNKELBERG, 1987). However, the share of employment in small businesses also may be regarded as a proxy for an industry's minimum efficient business size. The smaller an industry's minimum efficient business size is, the fewer the resources that are needed to successfully enter the market are, which makes it more likely that new businesses will emerge in that industry.

An issue related to a potential founder's qualification and minimum efficient size is the technological regime that holds sway in an industry. The concept of technological regime characterizes the nature of innovation activity in an industry, particularly the role of small and large firms (AUDRETSCH, 1995, 39- 
64; WINTER, 1984). A technological regime is called "entrepreneurial" if a high share of innovation activity is conducted by small firms; whereupon, entrants have a relatively good chance to compete successfully. In a "routinized" regime, the incumbent large firms have the innovative advantage and small firms play only a minor role. Therefore, the survival chances of businesses entering such a market can be assumed to be comparatively small.

Lower levels of capital intensity in an industry mean that less investment is needed to enter the market, which has a salutary effect on start-up activity. Likewise, a high level of new business formation can also be expected in industries with low labor unit costs. Lower levels of capital intensity and relatively high labor unit costs may also indicate industries in which a higher proportion of relevant resources reside in skilled labor rather than being incorporated in equipment. In such industries, highly-skilled employees may face relatively high incentives to exit a business and start their own businesses because they want to appropriate the full value of their skills, which employers tend to underestimate as a result of information asymmetry (AUDRETSCH, 1995). A low level of capital user costs indicates low barriers to entry and should be associated with high start-up rates.

The empirical results concerning the impact of unemployment on new business formation is rather contradictory and unclear. On the one hand, it could be argued that unemployed workers face rather low opportunity costs when starting their own businesses; hence, a high level of unemployment may lead to relatively large numbers of start-ups. On the other hand, high unemployment may indicate relatively low demand and correspondingly bad prospects for a successful start-up. In most of the empirical studies, the impact of the unemployment rate on 
new business formation was found to be weakly significant or insignificant (cf. ReYNOLDS et al., 1994; Evans and SIEGFRIED, 1994; Geroski, 1995). A few analyses have found that the percentage change in the number of unemployed had a negative impact on new business formation activity (cf. REYNOLDS et al. , 1994; SUTARIA, 2001; SUTARIA and HICKS, 2004). However, in an analysis on the level of individuals WAGNER and STERNBERG (2004) found that being unemployed increases the propensity to be a nascent entrepreneur.

There is little doubt that growing demand should be stimulating for startups. Yet, it is not quite clear whether the demand for the products of the specific industry or the overall demand is more important in this respect. If the level of start-ups in an industry is related to the stage in its life cycle (GORT and KLEPPER, 1982), then the development of demand on the industry level should be more important.

Another stylized fact of cross-regional analyses is a positive relationship between the level of new business formation and population density. ${ }^{9}$ The exact reason for this result is largely unclear because regional density may serve as a proxy for all kinds of regional influences, such as the availability and cost of needed resources like floor space and qualified labor, the presence of specialized services and venture capital ${ }^{10}$, spatial proximity to customers and to other businesses in the industry, the regional knowledge stock and knowledge spillovers (cf. Krugman, 1991), quality of life (Pennings, 1982) etc. Density may also be regarded as an indicator of innovativeness if agglomerations are characterized by a high level of innovation activity, as is frequently stated in the literature (for an overview see FRITSCH, 2000). In this interpretation, a positive relationship 
between density and start-up activity implies that a high level of innovativeness is conducive to new firm formation processes.

\section{Overview of new business formation in Germany from 1983 to 1997}

Our information on start-ups is generated from the German Social Insurance Statistics (see FRITSCH and BRIXY, 2004, for a description of this data source). The data are comprised of the yearly number of new businesses in the 74 West German planning regions for 52 private-sector industries in the period from 1983 to 1997 . Because, the data cover only establishments with at least one employee other than the founder; start-ups of businesses that remain very small without any employees are not included. We exclude new businesses with more than 20 employees in the first year of their existence; as a result, a considerable number of new subsidiaries of large firms contained in the database are not counted as startups. ${ }^{11}$ Although, the database only includes information at the establishment level; a comparison with information on the regional distribution of headquarters of newly founded firms reveals a rather high correlation, thus allowing our data to also be regarded as an indicator for regional entrepreneurship (see FRITSCH and BRIXY, 2004, and the analyses in FrITSCH and GROTZ, 2002). Planning regions are functional spatial units somewhat larger than labor-market areas consisting of at least one city and the surrounding area (see figure 2). ${ }^{12}$

According to our data, there were about 126 thousand private sector startups per year in the period under examination. Over the years, the number of startups increased slightly with a relatively distinct rise between 1990 and 1991. The difference between the average number of start-ups in the 1983 to 1989 and the 1990 to 1997 periods was about 12.3 percent. The majority of the new businesses, 
about 92.5 thousand per year (73.4 percent of all start-ups), were in the service sector compared to about 14.4 thousand new establishments per year (11.5 percent) in manufacturing. ${ }^{13}$ There was an overall trend towards an increasing share of start-ups in the service sector and a corresponding decreasing share in manufacturing sector (figure 1). In the service sector, the largest number of new establishments was set up in wholesale and resale trade, hotels and inns, and the non-specified "other" services. In manufacturing, most start-ups were in steel processing, motor vehicles, electrical engineering, furniture, and food (table 1).

(Figure 1 about here!)

(Table 1 about here!)

Not surprisingly, most of the start-ups (52.6 percent) were located in the agglomerations, while only 15.1 percent were in rural areas (table 2). The share of new businesses in the service sector was relatively high in agglomerations (76.4 percent) and the lowest in rural regions (67.5 percent). To compare the level of start-up activity between the regions, we also calculated start-up rates by dividing the number of start-ups by the number of employees in a certain industry and region. ${ }^{14}$ The average yearly start-up rate (number of new businesses per 1,000 employees) of 7.24 (table 2 ) means that per year about every $138^{\text {th }}$ employee started a new business. Generally, start-up rates tend to be higher in the service sector than in manufacturing.

(Table 2 about here !)

(Figure 2 about here!) 
Taking the private sector as a whole, we find the lowest start-up rates in the agglomerations. While for manufacturing, the highest start-up rate is in the moderately congested regions, the rural areas show the highest rates for services and other industries. Despite these differences, however, the regional distribution of start-up rates in the two sectors is rather similar to the picture that is produced for all private sectors (figure 2). Generally, start-up rates tend to be higher in the northern part of the country but relatively high rates are also found on the western and southern border.

\section{Variation of new business formation over industry, space, and time}

Multidimensional analysis allows different categories of influences to be examined simultaneously. ${ }^{15}$ In our approach, these dimensions are industry, space, and time. We analyze to what extent the number of start-ups in a certain industry and region during a certain year is determined by factors that are specific to the respective industries, regions, and years. In doing so, we particularly try to account for interregional differences in industry-specific factors. In the first step of analysis, we break down the total variance of the number of start-ups into three dimensions: industry, region, and time. We estimate the number of start-ups in an industry, region, and year $\left(y_{i r t}\right)$ as

(1) $y_{i r t}=\beta_{0}+e_{i r t}+u_{i r}+v_{r}$

The subscripts $i, r$, and $t$ represent the three dimensions of analysis. In our model, dimension $t$ is time (1983-1997), dimension $i$ is industry (52 industries), and dimension $r$ is space (74 West German regions). If an item has all three subscripts irt, it varies across all three dimensions. If an item has two subscripts, it varies across two dimensions, and so on. The variables $e_{i r}, u_{i r}$, and $v_{r}$ represent the 
random variables at the three dimensions, which follow a normal distribution with $E\left(e_{i r t}\right)=E\left(u_{i r}\right)=E\left(v_{r}\right)=0$ and $\operatorname{var}\left(e_{i r t}\right)=\sigma_{e}^{2}, \operatorname{var}\left(u_{i r}\right)=\sigma_{u}^{2}, \operatorname{var}\left(v_{r}\right)=\sigma_{u}^{2}$.

The estimation procedure used was iterative generalized least squares. We obtain a value of 33.20 for the constant term $\left(\beta_{0}\right)$ in the estimation for the number of yearly start-ups in all private sectors (table 3 ). This gives us the average number of start-ups in an average industry and region during an average year. Restricting these estimations to manufacturing or services resulted in an average number of 5.58 yearly start-ups per industry and region in manufacturing and 104.17 new businesses in the service sector. We found the highest variance for the random variable $u_{i r}$, indicating that the largest part of variation in the number of new businesses is found across industries $\left(\sigma_{u}^{2}\right)$. Considerably less variation could be attributed to region $\left(\sigma_{v}^{2}\right)$, and the smallest share of variation in start-up activity was found over time $\left(\sigma_{e}^{2}\right)$.

\section{(Table 3 about here!)}

We carried out the same procedure for the start-up rates that account for industry size because the high variation in the numbers of start-ups between industries is to some degree the result of differences in their economic potential. In this case, the smallest amount of variation was found across regions (table 3). In manufacturing as well as in the estimates for all private industries, the highest share of variance could be attributed to time. Estimates limited to the service sector showed that industry affiliation was responsible for most of the variation. Obviously, market dynamics play a relatively pronounced role for start-up activity in the service industries. A comparison of the results for the two indicators of start-up activity (i.e., the number of new establishments and the start-up rate) 
highlights the impact of differences in employment and employment changes on the start-up rate. The higher variance of start-up rates across industry in estimates limited to manufacturing indicates that manufacturing industries differ more with regard to employment than with regard to the number of start-ups. The opposite seems to be the case for the service industries. For all three sector definitions, the variance across regions is much smaller for start-up rates than it is for the number of start-ups. Variation over time is much higher for start-up rates than it is for the number of start-ups. This reflects a considerable impact of changes in employment: the denominator of the start-up rate.

\section{Multivariate analysis}

\subsection{Estimation procedure}

The analysis of the variation of new business formation across the different dimensions showed that the start-up rate was significantly shaped by the change in employment in the respective industry and region (cf. table 3). This is one reason why this rate is a questionable indicator in multivariate analyses of new business formation and entrepreneurship over time. Another argument against using the start-up rate in longitudinal analyses is that independent variables with the number of employees as the denominator are affected by employment changes. As a consequence, the estimates for such independent variables may suffer from a positive pseudo-correlation with the start-up rate. In our analysis, this is particularly relevant for the share of employees in small establishments, labor unit costs, and the unemployment rate. ${ }^{16}$ For these reasons, we used the number of start-ups instead of the start-up rate as the dependent variable in our analyses of the factors determining new business formation. 
Because the number of start-ups which is our dependent variable is of a count-data character we applied negative-binomial (negbin) regression for this analysis. This method is based on the assumption that the counts result from a stochastic poisson-type process. An ordinary negbin regression would, however, lead to the problem of having "too many" zero values, which implies a violation of underlying distribution assumptions (see Greene, 2003, pp. 931-939). Given the high degree of regional and industrial disaggregation in our data, such zero-value cases represent a considerable share of all observations. For an analysis across all private sectors, this share amounts to 28.2 percent. In manufacturing it is 34.17 percent and in services the proportion of observations with no start-up in a given industry, region, and year is 10.0 percent. One solution to this problem would be to apply a "truncated" negbin-approach, i.e., to exclude those observations that had no start-ups in a given year. However, because observations with zero startups are most likely to occur in industries and regions with a relatively low level of new business formation activity, omission of these observations would lead to a sample that is biased towards large industries and regions with many new establishments. To avoid this problem, we applied a zero inflated negbin approach. This type of model assumes that zero values may result from two different kinds of regimes. Under the first regime, the probability of a positive count (i.e., start-up) in an industry within a certain region is about zero. In this case, a zero observation can, therefore, not be regarded a result of a stochastic poisson process. Under the second regime, the zero observations are assumed to be an outcome of such a poisson process with some positive probability that a start-up in the respective industry and region will occur. The zero inflated negbin approach tries to exclude those zero counts that cannot be regarded to result from a poisson process. This is done here using a logit model with the number of 
employees in 1,000 employees lagged one year in each industry and region as exogenous variable (cf. Long, 1997, chapter 8 and Greene, 2003, chapter 19.9). In our analysis, we found that the estimates of truncated and zero inflated negbin models were very similar; thus, using one approach instead of the other does not seem to have a significant impact on the results. However, missing values in some of the exogenous variables led to some unavoidable sample bias ${ }^{17}$.

There may be considerable autocorrelation over time because industries and regions with a relatively high number of start-ups in a certain year will tend to have correspondingly high numbers of start-ups in other years. Moreover, an industry population in a region that is characterized by high numbers of start-ups is also quite likely to show comparatively high levels of change in the number of start-ups over time. Such an effect would imply heteroscedasticity. Analyses that neglect this cluster-correlated data situation will generally underestimate the true variance and lead to test statistics with inflated type I errors. To avoid these problems, we apply the correction procedure developed by HUBER (1967) and WHITE (1980) which provides an unbiased covariance matrix estimator that is robust with regard to this type of heteroscedasticity and autocorrelation over time, even if the model should be incorrectly specified. ${ }^{18}$

\subsection{Variables}

Table 4 shows the indicators used in our final model for assessing the importance of the different factors on the number of new businesses in a certain industry, region, and year as well as the signs of coefficients that we expect based on the evidence found in earlier studies. While the regional working population is an indicator for the pool of potential entrepreneurs, the share of industry employment 
explores as to what extend new businesses are set up by employees of the same industry. The unemployment rate in a given region and year indicates the role of unemployed persons in new firm formation activity. We are able to identify the short-term unemployed, which include only those persons which were unemployed for less than one year. Comparing the results of models with the short-term unemployment rate to models with the rate of the longer-term unemployed reveals that the latter has hardly any statistically significant effect on new business formation. This indicates that the short-term unemployed are more likely to set up a new business. Obviously, the longer-term unemployed cannot be regarded as a potential pool of entrepreneurs. Therefore, we include the short-term unemployment rate (share of short-term unemployed persons in the workforce) in the model.

Small business presence measured as the share of employees in establishments with less than 50 employees in a given region, industry, and year indicates the role of employment in small establishments as a source of start-ups. Our measure of minimum efficient size goes back to COMANOR and WILSON (1967, p. 428) and is quite frequently used in other analyses (see for example AUDRETSCH, 1995). COMANOR and WILSON argue that the larger-scale establishments of an industry should be relatively efficient because, otherwise, additional smaller units would have emerged. This implies that the smaller establishments are either newly founded or declining businesses which suffer from size disadvantages. ${ }^{19}$ The indicator for the entrepreneurial character of the technological regime measures the importance of small establishments for R\&D activity. Note that we calculate the technological regime indicator for each industry in each region separately so that the character of the technological regime in that industry may differ across 
regions as is suggested by some authors (SAXENIAN, 1994). We find that the indicator for the technological regime highly correlates with indicators that measure the qualification level of the workforce in the industry and region, such as the share of employees with a university degree. One can expect a positive relationship between the qualification variable and the level of start-up activity because the propensity of individuals to set up a new business rises as their level of qualification increases. (BATES, 1990). In our analyses, estimates with the indicator for the technological regime lead to a better fit than those based on the measures of the qualification level; therefore, we omitted the variables for shares of a certain qualification.

Unfortunately, our information about the number of patents that have been registered by inventors located in a region only covers the years from 1992 to1994. We use this information to create three dummy variables for the innovativeness of the region. Regions are classified according to the number of patents per 1,000 persons in the workforce in these three years. These dummies are assigned the value zero if the number of patents is in the lower quartile of all regions, and they assume the value one if the number of patents is in the second (patent 25-50), third (patent 50-75), or in the upper quartile (patent 75-100), respectively. This implies the assumption that the level of innovativeness in the regions has remained fairly constant over the period of analysis. The variables capital intensity, labor unit cost, and capital user cost are important industry characteristics that may show important variation over time. Our indicator for change of demand is the percent change of gross domestic product of the respective industry that showed to have a greater impact than the national or regional demand did. In order to account for unobserved region-specific effects, 


\section{Regional Studies}

16

dummy variables for the planning regions have been included. To avoid problems of reversed causality, all independent variables are lagged by one year.

(Table 4 about here!)

We find a considerable degree of spatial autocorrelation in our data; i.e., new business formation processes in adjacent regions are not independent but related in some way. There are two possible explanations for this high degree of spatial autocorrelation. One is that a significant number of entrepreneurs set up a business in an adjacent region. However, this seems quite unlikely given the considerable size of the planning regions and the fact that founders of new businesses tend to locate their businesses in close proximity to their homes (JOHNSON and CATHCART, 1979b; MUELLER and MORGAN, 1962; COOPER and DUNKELBERG, 1987). A more likely explanation for this spatial autocorrelation is that an entrepreneurial attitude or technological regime influences geographical entities that are larger than planning regions. In fact, AUDRETSCH and FRITSCH (2002) found that a certain type of growth regime tends to apply to a larger geographical area. To account for the spatial autocorrelation, an autoregressive error model that includes the weighted average of the disturbance terms of adjacent regions would be appropriate (ANSELIN, 1988). Such a model has to be estimated by a procedure that maximizes a likelihood function containing these weights. As our dataset contains 52,226 observations (for all private sectors), the weighting matrix for the error terms has the dimension 52,226 x 52,226 and is not computable due to technical restrictions. To overcome this problem, we apply a spatial cross-regressive model to account for the effects of the adjacent region by including dummy variables for the different Federal States (Laender). This type of model has the advantage because it can be estimated with standard estimation 
procedures. The German Federal States (Laender) are also an important level of policy making; hence, this variable may also indicate the effect of policy measures operated at that level. Table 5 provides descriptive statistics for the independent variables that have been included into the final model.

(Table 5 about here!)

Our multidimensional approach, as already stated in the introduction, may give us a clearer picture of the relationships than the analyses which account for only a single dimension. However, the number of dimensions of a certain variable may have an effect on the coefficients. If a variable has only variation over one (e.g., our patent indicator) or two (e.g., labor unit cost) dimensions then the variance is much less pronounced as compared to indicators that vary over all three dimensions. One could, therefore, expect that the impact of variables with variance over less than three dimensions is somewhat underestimated in comparison to indicators that vary over all three dimensions.

\subsection{Results}

Table 6 displays the results of the zero-inflated negbin models for all private sectors and for manufacturing and services taken together. Estimates limited to manufacturing or to the service industries are shown in table 7. The strong impact of the regional working population on the number of newly-founded businesses clearly indicates the importance of the workforce as a source of entrepreneurs. This variable also stands for agglomeration economies indicating a positive effect of density on new business formation. This finding is also consistent with the hypotheses that emphasize the role of spatial proximity and knowledge spillovers for economic development (cf. KRUGMAN, 1991). Due to a high correlation 
between the number of working population and population density, it is not possible to test for the effect of density with a separate variable in models that contain the size of the workforce. Note that no non-linearities in the relationship between working population and the number of start-ups could be found.

Due to the fact that the coefficients for the share of employment in the industry in which the new businesses are set-up are about as significant as those found for the workforce suggest that a considerable fraction of the founders come from the same industry. Obviously, industry specific qualifications and knowledge plays an important role in many of the new businesses. The results for the short-term unemployment rate indicate that start-ups out of unemployment mainly take place in the service sector. In the estimates limited to start-ups in manufacturing, the short-term unemployment rate is not statistically significant. The share of long-term unemployed persons or a change in the unemployment rate had no significant influence on the number of start-ups.

(Table 6 about here!)

(Table 7 about here!)

Our indicator for small business presence (share of employees in small establishments with less than 50 employees) was highly correlated with the measure of minimum efficient size (number of employees representing the 75th percentile of establishments in the industry) as well as with the indicator for the technological regime; therefore, these variables are included in separate models. We found that the indicator of minimum efficient size (model II) had a stronger impact on new business formation than the measure for small business presence (model I) ${ }^{20}$ This suggests that the positive relationship between small business 
employment and start-up activity that has been found in cross-regional analyses may be largely due to a regional concentration of industries with low minimum efficient size. Our indicator for the technological regime in an industry in a certain location had a considerable impact on start-ups in services and in manufacturing. The positive sign of the respective coefficients clearly indicates that an entrepreneurial character of an industry is conducive to start-up activity. This confirms the results attained by AUDRETSCH (1995) in analyses of a cross-section of industries. In models where the indicator for the technological regime and the measure of small firm presence had both been included, the dominant effect was found for the technological regime indicator. Variables reflecting the formal qualifications of the regional workforce (e.g., share of employees with a university degree) were only significant in models that did not include the indicator for the technological regime. We found considerable correlation between these variables with the technological regime indicator clearly outperforming the qualification measures in models that contained both variables. ${ }^{21}$

Remarkably, in analyses of the data that do not account for regional differences, the indicator for the technological regime of the industry was found to have no statistically significant impact on start-up activity. This suggests that there is an important degree of interregional variation with respect to the character of the technological regime in an industry. A case was made for this by SAXENIAN (1994) in her comparison of the computer industry along Route 128 and in Silicon Valley. Therefore, analyses on the level of industries that do not account for such regional differences may be misleading.

The level of capital intensity, labor unit cost, and capital user cost were significant with the expected sign. No significant impact could be found for 
changes of these factors. Change in the gross domestic product (GDP) of the respective industry in the preceding year had a significantly stronger impact than changes in the national figure; consequently, the national GDP change is not included in the models. The estimates show that changes in demand are of significant importance for new businesses set-up in all sectors. ${ }^{22}$ The number of patents granted to private firms and other institution (e.g., universities) located in the region represents an overall indicator for the level of regional innovation activity. The results for our measure of regional innovativeness - regional dummies based on the patent density - signify that a relatively high level of innovation in a region is conducive to start-up activity, particularly for start-ups in manufacturing industries where significance of this variable was higher than for start-ups in the service sector.

If the regional dummies which account for the unobserved region-specific effects are omitted, the coefficients for the technological regime indicator and the regional innovativeness indicator come out to be somewhat larger, but all the other coefficients remain unaffected. The Laender-dummies that are supposed to capture the effect of spatial autocorrelation prove to be highly significant; hence, indicating that regions belonging to the same Federal State (Land) have things in common. However, the inclusion of this variable for effects of spatial autocorrelation did not lead to any changes in the basic structure of the other influences on the number of start-ups.

There are a number of interesting differences of the determinants of startups between manufacturing and the service sector (table 7). The higher value of the coefficient for the working population in services indicates a higher propensity to start a business in this sector. The lower coefficient for the share of industry 
employment in services suggests that start-ups in this sector require less of an industry-specific knowledge as is the case for new businesses in manufacturing. Also, start-ups out of short-term unemployment seem to play a greater role in services than in manufacturing. We find higher coefficients for capital intensity in manufacturing, whereas the effect of labor unit costs is lower in models limited to the service sector. The indicator of minimum efficient size has greater importance in the service sector suggesting a stronger entry deterring effect of size requirements than in manufacturing. Dummies for industry affiliation and for the years of our observation period have been insignificant if included into our models. These dummies are not contained in the models presented here because of some correlation of these dummies with other variables such as GDP change, unemployment rate, and industry characteristics.

A number of variables had been tested but did not prove to be statistically significant; therefore, they are also omitted in the models presented in table 6 and table 7. For example, a variable for the presence of venture capital firms in the region or the share of employees in the banking sector that were meant to represent the local availability of capital had no effect. We also tested a number of interaction terms, particularly, with industry dummies and with the industry GDP growth rate in order to detect differences in the effect of variables over the product life cycle (cf. AGARWAL and GoRT, 2002). However, none of these variables proved to be statistically significant.

\section{Conclusions}

Our multidimensional analysis of new business formation in Germany confirmed a number of results from pure cross-sectional studies. We found that the regional 


\section{Regional Studies}

dimension plays a key role in new business formation processes; hence, empirical studies may gain important insights by accounting for space. Likewise, studies that focus on regions should be aware of significant differences between industries. Although, the more differentiated data and the higher level of sophistication in the analysis did not substantially contradict the results of previous studies; we were able to shed some new light on a number of issues.

Above and beyond a confirmation of earlier studies, there are at least four results that we find/found to be particularly interesting. Firstly, we were able to show that it is only short-term unemployment that may have an effect on new business formation while long-term unemployment remained insignificant. This impact of the short-term unemployment rate was, however, only significant for start-ups in the service sector and not for new businesses in manufacturing. Secondly, the positive influence of small business presence on new business formation that has been found in many cross-regional analyses (cf. REYNOLDS, STOREY, and WeSTHEAD, 1994) may, to a considerable extent, be related to the minimum efficient size of the industries that are located in the region. Thirdly, we could demonstrate a significant, positive relationship between the entrepreneurial character of an industry in a certain location and the number of start-ups. This clearly indicates that the characteristics of the technological regime and, therefore, of innovation processes play an important role in the formation of new businesses. The significant link between innovation activities and a considerable part of new business formation processes is also underlined by the positive impact that we find for the level of inventions in a region as measured by dummies based on the number of patents per 1,000 employees. These results clearly indicate that a considerable part of new firm formation is closely related to innovation activity 
and can be regarded as an important part of the regional (!) innovation system.

Fourthly, it is quite remarkable that, although there are some differences between the large economic sectors with regard to certain determinants of new business formation, we found that the same empirical model can be applied to all of the large sectors. This is underlined due to the fact that industry dummies as well as interaction variables of industry dummies with the determinants of new business formation in our model did not prove to be of statistical significance. This indicates that the process of new business formation in the different sectors nearly follows the same principles, although the strength of some determinants may be more or less pronounced in certain industries.

The implications for a policy that wants to stimulate new business formation are straightforward. If, as it has been shown in our analysis, the regional workforce is a main source of new ventures, it would be appropriate to direct policy measures to the potential founders; e.g., trying to raise their entrepreneurial spirit and improve their qualification. According to our results, a considerable part of new business formation processes is linked to innovation activities in the region and constitutes a part of the regional innovation system. Particularly, an entrepreneurial technological regime with innovative small firms seems to be a source and a stimulus for new business formation. A policy aiming at stimulating small business formation could focus on this part of the regional economy. This may involve measures that try to improve technology transfer such as strengthening the network between public research institutions and private sector firms as well as paving the way for innovative spin-offs that may emerge from public research. The strong impact of regional characteristics that we found in our analysis suggests that measures which aim at stimulating new business formation 
should account for the regional dimension. It could, therefore, be appropriate to involve regional authorities in such a policy or to implement the measures more or less completely at the regional level.

Our analysis has clearly demonstrated that a more disaggregated and differentiated empirical approach may lead to considerable advances in the understanding of reality. Therefore, further research on new business formation processes should take industries and regions seriously and try to account for both of the two dimensions. In an analysis, the main focus should be on the link between start-ups and the level of innovation activity as well as its characteristics in an industry and region. What are the main causal relationships, how pronounced are these relationships, and what does this mean for economic development? Further investigation of these issues should advance our understanding of new firm formation and the process of economic development. 


\section{References}

Agarwal, R. and GoRT, M. (2002) Firm and Product Life Cycles and Firm Survival, American Economic Review 92, 184-190.

ANSELIN, L. (1988) Spatial Econometrics: Methods and Models. Kluwer Academic Publisher, Dordrecht.

ARmington, C. and ACs, Z. J. (2002) The Determinants of Regional Variation in New Firm Formation, Regional Studies 36, 33-45.

AUDRETSCH, D. B. (1995) Innovation and Industry Evolution. MIT Press, Cambridge.

AudRETSCH, D. B. and FRITSCH, M. (1994) On the Measurement of Entry Rates, Empirica 21, 105-113.

AudRETSCH, D. B. and FRITSCH, M. (1999) The Industry Component of Regional New Firm Formation Processes, Review of Industrial Organization 15, 239252.

AudretsCh, D. B. and FritsCH, M. (2002) Growth Regimes over Time and Space, Regional Studies 36, 113-124.

BATES, T. (1990) Entrepreneur Human Capital Inputs and Small Business Longevity, Review of Economics and Statistics 72, 551-559.

BeEsley, M. E. and HAmilton, R. T. (1984) Small firms' seedbed role and the concept of turbulence, Journal of Industrial Economics 33, 217-231.

BRYK, A. S. and RAUDENBUSH, S. W. (1992) Hierarchical Linear Models. Sage, Newbury Park. 
BUNDESFORSCHUNGSANSTALT FÜR LANDESKUNDE UND RAUMORDNUNG (1987)

Laufende Raumbeobachtung: Aktuelle Daten zur Entwicklung der Städte, Kreise und Gemeinden 1986. Bonn.

CArree, M. A. and ThuriK, A. R. (2003) The Impact of Entrepreneurship on Economic Growth, in Acs, Z. A. and Audretsch, D. B. (Eds) Handbook of Entrepreneurship Research, pp. 437-471. Kluwer, Boston.

Chell, E., Haworth, J. and BreARLEy, S. (1991) The Entrepreneurial Personality. Routledge, London.

COMANOR, W. S. and WILSON, T. A. (1967) Advertising Market Structure and Performance, Review of Economics and Statistics 44, 423-440.

COOPER, A. and DunKelberG, W. C. (1987) Entrepreneurial Research: Old Questions, New Answers and Methodological Issues, American Journal of Small Business 11, 11-23.

Deutsche Bundesbank (German Federal Bank) (various volumes) Monatsberichte (Monthly Reports). Frankfurt a. Main.

EvAns, L. and SiEgFRIED, J. (1994) Empirical Studies of Entry and Exit: A Survey of the Evidence, Review of Industrial Organization 9, 121-156.

Fotopoulos, G. and Spence, N. (1999) Spatial Variation in New Manufacturing Plant Openings: Some Empirical Evidence from Greece, Regional Studies 33, 219-229.

FRITSCH, M. (2000): Interregional differences in R\&D activities - an empirical investigation, European Planning Studies 8, 409-427. 
FrITSCH, M. and GROTZ, R. (Eds.) (2002) Das Gründungsgeschehen in Deutschland - Darstellung und Vergleich der Datenquellen (New Firm Formation in Germany - Exposition and Comparison of Data Sources). Physica, Heidelberg.

FRITSCH, M. and BRIXY, U. (2004) The Establishment File of the German Social Insurance Statistics, Schmollers Jahrbuch / Journal of Applied Social Science Studies 124, 183-190.

FritsCH, M. and MuelLer, P. (2004) The Effects of New Firm Formation on Regional Development over Time, Regional Studies 38, 961-975.

GEROSKI, P. (1995) What do we know about entry? International Journal of Industrial Organization 13, 421-440.

GoldsteIn, H. (1995) Multilevel Statistical Models. Wiley, New York.

Gort, M. and KLePPER, S. (1982) Time Paths in the Diffusion of Product Innovations, Economic Journal 92, 630-653.

GreENe, W. H. (2003) Econometric Analysis, $4^{\text {th }}$ edition. Prentice Hall, New York.

GREIF, S. (1998) Patentatlas Deutschland - Die Räumliche Struktur der Erfindungstätigkeit (Patent Atlas Germany - The Spatial Structure of Inventive Activity). Deutsches Patentamt, Munich.

HUBER, P. J. (1967) The behavior of maximum likelihood estimates under nonstandard conditions, Vol. 1. University of California Press, Berkeley.

Johnson, P. S. and CATHCART, D. G. (1979) The Founders of New Manufacturing Firms: A Note on the Size of their "Incubator" Plants, Journal of Industrial Economics 28, 219-224. 
Johnson, P. S. and CATHCART, D. G. (1979) New Manufacturing Firms and Regional Development: Some Evidence from the Northern Region, Regional Studies 13, 269-280.

JOHNSON, P. and PARKER, S. (1996) Spatial Variations in the Determinants and Effects of Firm Births and Deaths, Regional Studies 30, 679-688.

KeEble, D., Walker, S. and Robson, M. (1993) New Firm Formation and Small Business Growth: Spatial and Temporal Variations in the United Kingdom, Employment Department, Research Series, No 15, September.

Krugman, P. (1991) Geography and Trade. MIT Press, Cambridge.

LONG, J. S. (1997) Regression Models for Categorical and Limited Dependent Variables. Sage Publications, Thousand Oaks.

Mueller, E. and Morgan, J. N. (1962) Location Decisions of Manufacturers, American Economic Review 52, 204-217.

Mueller, P. (2005) Entrepreneurship in the Region: Breeding Ground for Nascent Entrepreneurs?. Working Paper 05/2005, Faculty of Economics and Business Administration, Technical University of Freiberg.

PEnNINGS, J. M. (1982) The Urban Quality of Life and Entrepreneurship, Academy of Management Journal 25, 63-79.

Reynolds, P. D., Storey, D. J. and Westhead, P. (1994) Cross National Comparison of the Variation in New Firm Formation Rates, Regional Studies 27, 443-456.

SAXENian, A. (1994) Regional Advantage. Harvard University Press, Cambridge. 
SNiJders, T. A. B. and Bosker, R. J. (1999) Multilevel Analysis: An Introduction to Basic and Advanced Multilevel Modeling. Sage, London.

Sorensen, O. and AudiA, P. G. (2000) The Social Structure of Entrepreneurial Activity: Geographic Concentration of Footwear Production in the United States 1940-1989, American Journal of Sociology 106, 224-262.

Sorensen, O. and Stuart, T. E. (2001) Syndication Networks and the Spatial Distribution of Venture Capital Investments, American Journal of Sociology 106, $1546-1588$.

STATISTISCHES BundeSAMT (Federal Statistical Office) (various volumes): Fachserie 18 Volkswirtschaftliche Gesamtrechnung (National Accounting). Metzler-Poeschel, Stuttgart.

StOREY, D. J. (1994) Understanding the Small Business Sector. Routledge, London.

SutARIA, V. (2001) The Dynamics of New Firm Formation. Ashgate, Aldershot.

SUTARIA, V. and Hicks, D. (2004) New firm formation: Dynamics and determinants, Annals of Regional Science 38, 241-262.

Van Stel, A. and Storey, D. (2004) The Link Between Firm Births and Job Creation: Is there a Upas Tree Effect?, Regional Studies 38, 893-909.

WAGNER, J. (2004) Are Young and Small Firms Hothouses for Nascent Entrepreneurs?, Applied Economics Quarterly 50, 379-391.

WHITE, H. (1980) A heteroscedasticity-consistent covariance matrix estimator and a direct test for heteroscedasticity, Econometrica 48, 817-830. 
WAGNER, J. and StERnBERG, R. (2004) Start-up activities, individual characteristics, and the regional milieu: Lessons for entrepreneurship support policies from German micro data, Annals of Regional Science 38, 219-240.

WiLLiAMS, R. L. (2000) A note on robust variance estimation for clustercorrelated data, Biometrics 56, 645-646.

WINTER, S. G. (1984) Schumpeterian Competition in Alternative Technological Regimes, Journal of Economic Behavior and Organization 5, 287-320. 
31

\section{Tables and Figures}

Table 1: Average yearly number of start-ups in different industries from 1983 to 1997

\begin{tabular}{|c|c|c|c|c|c|}
\hline Industry & $\begin{array}{l}\text { Average no. of } \\
\text { start-ups per } \\
\text { year (percent } \\
\text { share in all } \\
\text { start-ups) } \\
\end{array}$ & $\begin{array}{l}\text { No. of } \\
\text { regions } \\
\text { with zero } \\
\text { start-ups } \\
\text { in a year } \\
\end{array}$ & Industry & $\begin{array}{l}\text { Average no. of } \\
\text { start-ups per } \\
\text { year (percent } \\
\text { share in all } \\
\text { start-ups) }\end{array}$ & $\begin{array}{l}\text { No. of } \\
\text { regions } \\
\text { with zero } \\
\text { start-ups } \\
\text { in a year }\end{array}$ \\
\hline Agriculture & $7,716(6.13)$ & 0 & $\begin{array}{l}\text { Jewelry, musical } \\
\text { instruments and toys }\end{array}$ & $230(0.18)$ & 239 \\
\hline Water, energy & $85(0.07)$ & 487 & $\begin{array}{l}\text { Wood (excluding } \\
\text { furniture) }\end{array}$ & $\begin{array}{c}111 \\
(0.09)\end{array}$ & 376 \\
\hline Coal mining & $4(0.00)$ & 1,071 & Furniture & $1,920(1.53)$ & 0 \\
\hline Other mining & $19(0.02)$ & 928 & Paper-making & $12(0.01)$ & 945 \\
\hline Chemicals & $177(0.14)$ & 267 & $\begin{array}{l}\text { Paper processing and } \\
\text { board }\end{array}$ & $119(0.09)$ & 410 \\
\hline Mineral oil processing & $7(0.00)$ & 1,019 & Printing & $775(0.62)$ & 24 \\
\hline Plastics & $432(0.34)$ & 70 & Textiles & $208(0.17)$ & 262 \\
\hline Rubber & $45(0.04)$ & 692 & Leather & $260(0.21)$ & 159 \\
\hline Stone and clay & $398(0.32)$ & 44 & Apparel & $598(0.48)$ & 47 \\
\hline Ceramics & $82(0.07)$ & 464 & Food & $1,572(1.25)$ & 0 \\
\hline Glass & $54(0.04)$ & 621 & Beverages & $68(0.05)$ & 548 \\
\hline Iron and steel & $15(0.01)$ & 946 & Tobacco & $2(0.00)$ & 1,079 \\
\hline Non-ferrous metals & $25(0.02)$ & 840 & Construction & $6,569(5.22)$ & 0 \\
\hline Foundries & $53(0.04)$ & 660 & Installation & 4,649 (3.69) & 0 \\
\hline Steel processing & $1,176(0.93)$ & 0 & Wholesale trade & $10,519(8.36)$ & 0 \\
\hline $\begin{array}{l}\text { Steel and light metal } \\
\text { construction }\end{array}$ & $655(0.52)$ & 26 & Resale trade & $\begin{array}{r}20,743 \\
(16.48)\end{array}$ & 0 \\
\hline $\begin{array}{l}\text { Machinery (non- } \\
\text { electrical excluding } \\
\text { office) }\end{array}$ & $587(0.47)$ & 33 & Shipping & $241(0.19)$ & 749 \\
\hline $\begin{array}{l}\text { Gears, drive units and } \\
\text { other machine parts }\end{array}$ & $360(0.29)$ & 75 & Traffic and freight & $6,482(5.15)$ & 557 \\
\hline Office machinery & $35(0.03)$ & 755 & Postal services & $457(0.36)$ & 0 \\
\hline Computers & $101(0.08)$ & 535 & Banking and credits & $812(0.65)$ & 15 \\
\hline Motor vehicles & $1,844(1.47)$ & 0 & Insurance & $2,051(1.63)$ & 0 \\
\hline Shipbuilding & $37(0.03)$ & 815 & Real estate and housing & $4,503(3.58)$ & 0 \\
\hline Aerospace & $21(0.02)$ & 868 & Hotels, inns etc. & $\begin{array}{l}16,448 \\
(13.07)\end{array}$ & 0 \\
\hline Electronics & $1,222(0.97)$ & 1 & Science, publishing etc. & $4,004(3.18)$ & 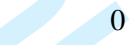 \\
\hline Fine mechanics & $714(0.57)$ & 20 & Health care & $7,273(5.78)$ & 0 \\
\hline Watches and gauges & $31(0.02)$ & 796 & Other private services & $\begin{array}{r}19,296 \\
(15.33)\end{array}$ & 0 \\
\hline Iron and metal goods & $493(0.39)$ & 53 & & & \\
\hline
\end{tabular}


Table 2: Average yearly number of start-ups in different sectors from 1983 to 1997 by type of region ${ }^{a}$

\begin{tabular}{|c|c|c|c|c|}
\hline $\begin{array}{l}\text { Average yearly } \\
\text { number of start-ups }\end{array}$ & Agglomerations & $\begin{array}{l}\text { Moderately } \\
\text { congested }\end{array}$ & Rural areas & All regions \\
\hline \multirow[t]{2}{*}{ All private sectors } & 66,253 & 40,612 & 18,999 & 125,854 \\
\hline & $(52.6 / 100)$ & $(32.3 / 100)$ & $(15.1 / 100)$ & $(100 / 100)$ \\
\hline \multirow[t]{2}{*}{ Manufacturing } & 7,169 & 4,972 & 2,309 & 14,450 \\
\hline & (49.6/ 10.8) & $(34.4 / 12.2)$ & $(16.0 / 12.1)$ & $(100 / 11.4)$ \\
\hline \multirow[t]{2}{*}{ Services } & 50,615 & 28,942 & 12,816 & 92,373 \\
\hline & $(54.8 / 76.4)$ & $(31.3 / 71.3)$ & $(13.9 / 67.5)$ & $(100 / 73.4)$ \\
\hline \multirow[t]{2}{*}{ Other industries } & 8,469 & 6,698 & 3,864 & 19,031 \\
\hline & $(44.5 / 12.8)$ & $(35.2 / 16.5)$ & $(20.3 / 20.3)$ & $(100 / 15.1)$ \\
\hline \multicolumn{5}{|l|}{$\begin{array}{l}\text { Start-up rate } \\
\text { (number of start-ups }\end{array}$} \\
\hline \multicolumn{5}{|l|}{ per 1,000 employees) } \\
\hline All private sectors & 7.06 & 7.29 & 7.81 & 7.24 \\
\hline Manufacturing & 1.84 & 1.95 & 1.89 & 1.89 \\
\hline Services & 9.41 & 12.82 & 14.89 & 10.87 \\
\hline Other industries & 7.68 & 8.70 & 11.00 & 8.53 \\
\hline
\end{tabular}


Table 3: Average number of start-ups and estimated variance by industry, region, and over time ${ }^{a}$

\begin{tabular}{|c|c|c|c|c|}
\hline \multirow[b]{2}{*}{ Number of start-ups } & \multirow[b]{2}{*}{ Average } & \multicolumn{3}{|c|}{ Variance by } \\
\hline & & time $\left(\sigma_{\mathrm{e}}^{2}\right)$ & industry $\left(\sigma_{\mathrm{uj}}^{2}\right)$ & region $\left(\sigma_{v}^{2}\right)$ \\
\hline \multirow[t]{2}{*}{ All private sectors } & 33.20 & 182.65 & $7,109.98$ & 503.64 \\
\hline & $(2.94)$ & $(1.10)$ & $(162.37)$ & $(104.92)$ \\
\hline \multirow[t]{2}{*}{ Manufacturing } & 5.58 & 8.05 & 83.48 & 12.07 \\
\hline & $(0.44)$ & $(0.06)$ & (2.37) & $(2.38)$ \\
\hline \multirow[t]{2}{*}{ Services } & 104.17 & 556.52 & $17,764.38$ & $6,372.82$ \\
\hline & $(10.30)$ & (7.06) & $(882.40)$ & $(1,293.69)$ \\
\hline \multirow{2}{*}{\multicolumn{5}{|c|}{$\begin{array}{l}\text { Start-up rate } \\
\text { (number of start-ups } \\
\text { per 1,000 employees) }\end{array}$}} \\
\hline & & & & \\
\hline \multirow[t]{2}{*}{ All private sectors } & 12.93 & $1,542.03$ & $1,287.85$ & 1.07 \\
\hline & $(0.62)$ & $(9.62)$ & $(32.43)$ & $(4.72)$ \\
\hline \multirow[t]{2}{*}{ Manufacturing } & 10.08 & $2,031.87$ & $1,077.06$ & 0.00 \\
\hline & $(0.70)$ & (15.59) & $(34.39)$ & $(0.00)$ \\
\hline \multirow[t]{2}{*}{ Services } & 18.44 & 592.43 & 802.93 & 1.77 \\
\hline & $(0.99)$ & $(7.58)$ & (41.83) & (12.40) \\
\hline
\end{tabular}

a: Standard deviation in parentheses 
Table 4: Definition of variables and expected sign of coefficient

\begin{tabular}{|c|c|c|}
\hline Variable & Operational definition & $\begin{array}{l}\text { Expected } \\
\text { sign }\end{array}$ \\
\hline Working population & $\begin{array}{l}\text { Number of employees and unemployed persons } \\
\text { (thousands) in a region and year as an indicator for } \\
\text { the pool of potential entrepreneurs (source: Social } \\
\text { Insurance Statistics and FEDERAL EMPLOYMENT } \\
\text { SERVICES) }\end{array}$ & + \\
\hline Share of industry employment & $\begin{array}{l}\text { Share of the employees in the same industry in the } \\
\text { respective region by year (source: Social Insurance } \\
\text { Statistics) }\end{array}$ & + \\
\hline Short-term unemployment rate & $\begin{array}{l}\text { Share of persons in a region which are unemployed } \\
\text { for less than one year on the regional workforce } \\
\text { (source: FEDERAL EMPLOYMENT SERVICES) }\end{array}$ & $+/-$ \\
\hline Small business presence & $\begin{array}{l}\text { Share of employees in establishments with less than } \\
50 \text { employees in a given region, industry, and year } \\
\text { (source: Social Insurance Statistics) }\end{array}$ & + \\
\hline Minimum efficient size & $\begin{array}{l}\text { The 75th percentile of establishment size when } \\
\text { establishments are ordered by size (number of } \\
\text { employees; source: Social Insurance Statistics). }\end{array}$ & - \\
\hline Technological regime & $\begin{array}{l}\text { The proportion of R\&D employees in } \\
\text { establishments with less than } 50 \text { employees over the } \\
\text { share of R\&D employment in total employment in } \\
\text { the respective region, industry, and year (source: } \\
\text { Social Insurance Statistics) }\end{array}$ & + \\
\hline $\begin{array}{l}\text { Dummies for regional } \\
\text { innovativeness }\end{array}$ & $\begin{array}{l}\text { Three variables based on the number of patents that } \\
\text { have been registered by inventors located in a } \\
\text { region in the } 1992 \text { to } 1994 \text { period (source: GERMAN } \\
\text { FEDERAL PATENT OFFICE taken from GREIF, 1998) } \\
\text { per 1,000 persons in the workforce (source: Social } \\
\text { Insurance Statistics). Dummies are assigned the } \\
\text { value zero if the number of patents is in the lower } \\
\text { quartile of all regions, and they assume the value } \\
\text { one if the number of patents is in the second (patent } \\
\text { 25-50), third (patent 50-75), or in the upper quartile } \\
\text { (patent 75-100), respectively. }\end{array}$ & + \\
\hline Capital intensity & $\begin{array}{l}\text { Gross capital assets expressed in terms of } 10,000 \\
\text { German marks (source: FEDERAL STATISTICAL } \\
\text { OFFICE, Fachserie18, various volumes) over the } \\
\text { number of employees (source: Social Insurance } \\
\text { Statistics) by industry and year }\end{array}$ & - \\
\hline Labor unit cost & $\begin{array}{l}\text { Gross income from dependent work per employee } \\
\text { over gross value added per employee (source: } \\
\text { FEDERAL STATISTICAL OFFICE, Fachserie } 18, \\
\text { various volumes) by industry over time. }\end{array}$ & - \\
\hline Capital user cost & $\begin{array}{l}\text { Nominal interest rate of ten-year government bonds } \\
\text { minus the rate of inflation (source: German Federal } \\
\text { Bank, various volumes) plus the average yearly } \\
\text { depreciation rate of gross capital assets (based on } \\
\text { FEDERAL STATISTICAL OFFICE, Fachserie18, various } \\
\text { volumes) within an industry over time }\end{array}$ & \\
\hline Change of demand & $\begin{array}{l}\text { Percent change of gross domestic product of the } \\
\text { industry in the preceding year (source: FEDERAL } \\
\text { STATISTICAL OFFICE, various volumes) }\end{array}$ & + \\
\hline
\end{tabular}


Table 5: Descriptive statistics of dependent variables

\begin{tabular}{|c|c|c|c|c|}
\hline Variable & Mean & $\begin{array}{l}\text { Standard } \\
\text { deviation }\end{array}$ & Minimum & Maximum \\
\hline & \multicolumn{4}{|c|}{ All private industries } \\
\hline Working population (in 1,000) (r) & 254.28 & 206.66 & 53.05 & 950.45 \\
\hline Share of industry employment (\%) (ir) & 1.88 & 7.57 & 32.95 & 70.94 \\
\hline $\begin{array}{l}\text { Share of small business employment (\%) } \\
\text { (ir) }\end{array}$ & 50.81 & 32.15 & 0.12 & 100 \\
\hline Short-term unemployment rate (\%) (r) & 7.86 & 2.30 & 4.38 & 14.57 \\
\hline Industry GDP growth rate (\%) (i) & 1.29 & 3.07 & -5.03 & 9.09 \\
\hline Minimum efficient size (i) & 159.59 & 348.23 & 8.83 & $2,358.21$ \\
\hline Technological regime (ir) & 0.71 & 0.88 & 0 & 17.98 \\
\hline Capital intensity $(1,000)(\mathrm{i})$ & $1,079.95$ & $2,089.71$ & 28.13 & 12,600 \\
\hline Labor unit cost (i) & 70.04 & 38.50 & 7.31 & 295.80 \\
\hline Capital user cost (\%) (i) & 9.58 & 1.56 & 5.49 & 13.37 \\
\hline \multirow[t]{2}{*}{$\begin{array}{l}\text { Average yearly number of patents per } \\
1,000 \text { employees }\end{array}$} & 1.49 & 0.71 & 0.37 & 3.06 \\
\hline & \multicolumn{4}{|c|}{ Manufacturing and services } \\
\hline Share of industry employment (\%) (ir) & 1.83 & 2.58 & 0 & 27.17 \\
\hline Industry GDP growth rate (\%) (i) & 1.23 & 3.08 & -5.03 & 9.09 \\
\hline $\begin{array}{l}\text { Share of small business employment (\%) } \\
\text { (ir) }\end{array}$ & 49.94 & 32.07 & 0.14 & 100 \\
\hline Minimum efficient size (i) & 121.73 & 170.89 & 9.24 & 975.40 \\
\hline Technological regime (ir) & 0.72 & 0.84 & 0 & 17.98 \\
\hline Capital intensity $(1,000)(\mathrm{i})$ & $1,076.04$ & $2,130.54$ & 28.13 & $12,579.28$ \\
\hline Labor unit cost (i) & 67.49 & 21.35 & 7.31 & 124.26 \\
\hline \multirow[t]{2}{*}{ Capital user cost (\%) (i) } & 9.54 & 1.51 & 5.49 & 13.37 \\
\hline & \multicolumn{4}{|c|}{ Manufacturing } \\
\hline Share of industry employment (\%) (ir) & 1.31 & 2.13 & 0 & 27.17 \\
\hline Industry GDP growth rate (\%) (i) & 0.77 & 3.05 & -5.03 & 9.09 \\
\hline $\begin{array}{l}\text { Share of small business employment (\%) } \\
\text { (ir) }\end{array}$ & 44.89 & 32.49 & 0.14 & 100 \\
\hline Minimum efficient size (i) & 150.56 & 188.16 & 20.97 & 975.40 \\
\hline Technological regime (ir) & 0.68 & 0.74 & 0 & 10.34 \\
\hline Capital intensity (i) & $1,102.09$ & $2,351.88$ & 28.13 & $12,579.28$ \\
\hline Labor unit cost (\%) (i) & 70.70 & 19.30 & 7.31 & 99.45 \\
\hline \multirow[t]{2}{*}{ Capital user cost (i) } & 10.02 & 0.93 & 8.69 & 12.78 \\
\hline & \multicolumn{4}{|c|}{ Services } \\
\hline Corrected working population (ir) & 245.83 & 197.29 & 46.69 & 943.36 \\
\hline Share of industry employment (\%) (ir) & 3.37 & 3.10 & 0 & 15.02 \\
\hline $\begin{array}{l}\text { Share of small business employment (\%) } \\
\text { (ir) }\end{array}$ & 64.08 & 26.11 & 2.00 & 100 \\
\hline Industry GDP growth rate (\%) (i) & 2.59 & 2.90 & -3.78 & 6.50 \\
\hline Minimum efficient size (i) & 37.63 & 48.33 & 9.24 & 183.02 \\
\hline Technological regime (ir) & 0.82 & 1.09 & 0 & 17.98 \\
\hline Capital intensity $(1,000)(\mathrm{i})$ & $1,000.06$ & $1,369.95$ & 69.57 & $4,391.66$ \\
\hline Labor unit cost (i) & 57.26 & 25.18 & 25.53 & 124.26 \\
\hline Capital user cost (\%)(i) & 8.14 & 1.99 & 5.49 & 13.37 \\
\hline
\end{tabular}

* Mean, minimum, and maximum of the mean over time for the dimension in parentheses. i: industry, r: region.

Deleted: $\mathscr{I}$ 
Table 6: Results of multi-level analyses of new business formation for all private sectors and for manufacturing plus services

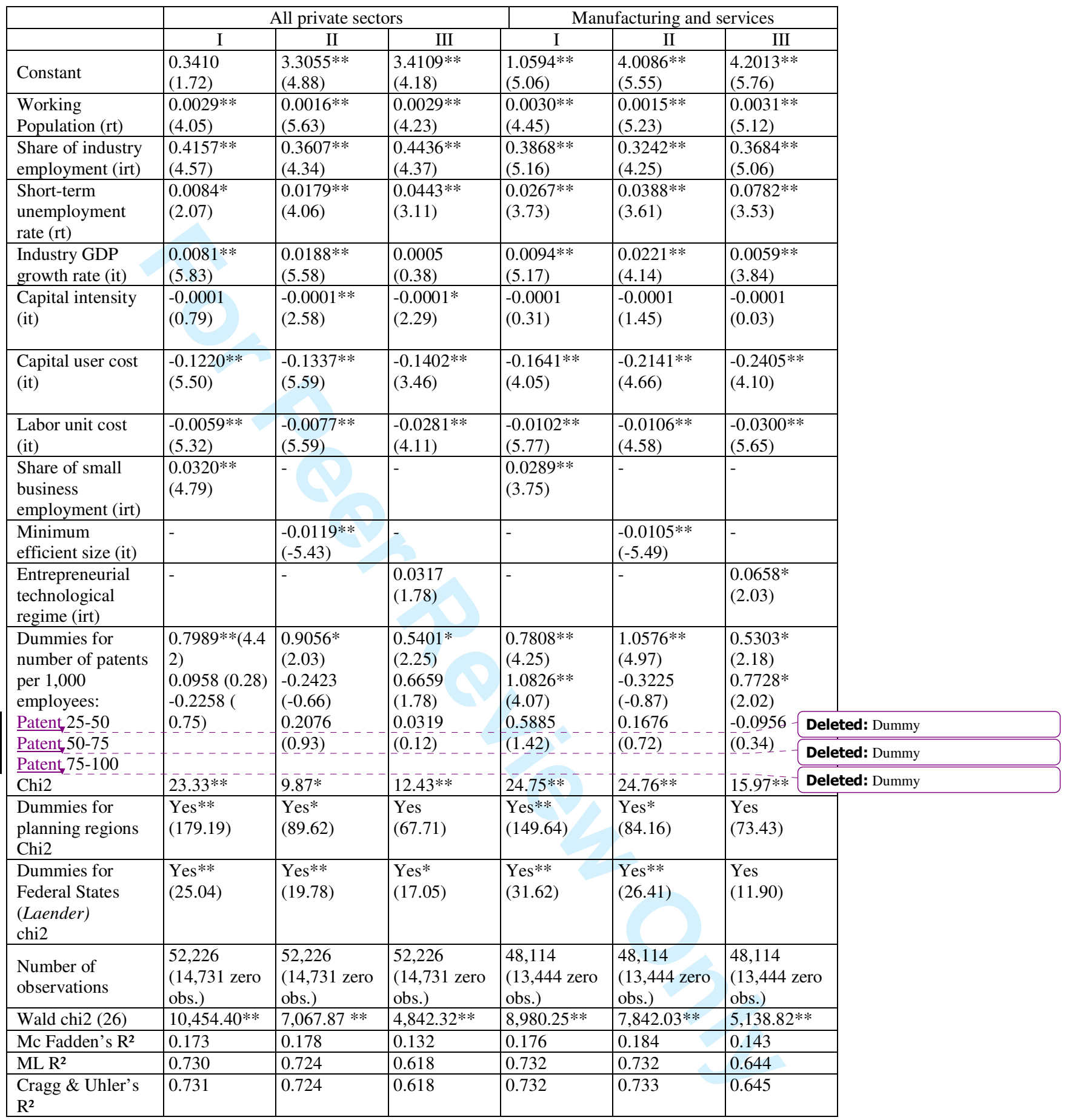

Zero inflated negbin model with standard errors adjusted for clustering; i: industry, r: region, t: time. Absolute z-statistics in parentheses; **: statistically significant at the 1 percent level, *: statistically significant at the 5 percent level. 
Table 7: Results of multi-level analyses of new business formation for manufacturing industries

\begin{tabular}{|c|c|c|c|c|c|c|c|}
\hline & \multicolumn{3}{|c|}{ Manufacturing } & \multicolumn{3}{|c|}{ Services } & \\
\hline & I & II & III & I & II & III & \\
\hline Constant & \begin{tabular}{|l|}
0.0076 \\
$(0.05)$
\end{tabular} & $\begin{array}{l}1.7759 * * \\
(4.54)\end{array}$ & $\begin{array}{l}1.9027 * * \\
(5.57)\end{array}$ & $\begin{array}{l}0.9242 * * \\
(3.66)\end{array}$ & $\begin{array}{l}2.7727 * * \\
(5.90)\end{array}$ & $\begin{array}{l}4.1767 * * \\
(5.39)\end{array}$ & \\
\hline $\begin{array}{l}\text { Working } \\
\text { population (rt) }\end{array}$ & $\begin{array}{l}0.0011^{* * *} \\
(4.86)\end{array}$ & \begin{tabular}{|l|}
0.0003 \\
$(1.45)$
\end{tabular} & $\begin{array}{l}0.0009 * * \\
(3.97)\end{array}$ & $\begin{array}{l}0.0034 * * \\
(6.87)\end{array}$ & $\begin{array}{l}0.0032 * * \\
(4.31)\end{array}$ & $\begin{array}{l}0.0009^{*} \\
(2.04)\end{array}$ & \\
\hline $\begin{array}{l}\text { Share of industry } \\
\text { employment (irt) }\end{array}$ & $\begin{array}{l}0.3613 * * \\
(6.88)\end{array}$ & $\begin{array}{l}0.2582 * * \\
(6.13)\end{array}$ & $\begin{array}{l}0.2731 * * \\
(4.57)\end{array}$ & $\begin{array}{l}0.2352 * * \\
(4.21)\end{array}$ & $\begin{array}{l}0.1732 * * \\
(4.93)\end{array}$ & $\begin{array}{l}0.2208^{* *} \\
(4.99)\end{array}$ & \\
\hline $\begin{array}{l}\text { Short-term } \\
\text { unemployment } \\
\text { rate }(\mathrm{rt})\end{array}$ & \begin{tabular}{|l|}
0.0015 \\
$(0.33)$
\end{tabular} & \begin{tabular}{|l}
-0.0099 \\
$(1.45)$
\end{tabular} & $\begin{array}{l}0.0176^{* *} \\
(3.71)\end{array}$ & \begin{tabular}{|l}
$0.0246^{* *}$ \\
$(3.56)$
\end{tabular} & $\begin{array}{l}0.0191 * \\
(2.05)\end{array}$ & $\begin{array}{l}0.0329^{* *} \\
(5.74)\end{array}$ & \\
\hline $\begin{array}{l}\text { Industry GDP } \\
\text { growth rate (it) }\end{array}$ & $\begin{array}{l}-0.0011 \\
(-1.06)\end{array}$ & $\begin{array}{l}0.0058 * * \\
(5.76)\end{array}$ & $\begin{array}{l}0.0078^{* *} \\
(6.76)\end{array}$ & $\begin{array}{l}0.0083 * * \\
(3.11)\end{array}$ & $\begin{array}{l}0.0238 * * \\
(6.46)\end{array}$ & $\begin{array}{l}0.0027 \\
(0.75)\end{array}$ & \\
\hline $\begin{array}{l}\text { Capital intensity } \\
\text { (it) }\end{array}$ & $\begin{array}{l}-0.0004 \\
(4.12)\end{array}$ & $\begin{array}{l}-0.0004 * * \\
(5.66)\end{array}$ & $\begin{array}{l}-0.0004 * * \\
(4.42)\end{array}$ & $\begin{array}{l}-0.0001 * * \\
(4.53)\end{array}$ & $\begin{array}{l}-0.0001 * * \\
(4.70)\end{array}$ & $\begin{array}{l}-0.0001 * * \\
(5.93)\end{array}$ & \\
\hline $\begin{array}{l}\text { Capital user cost } \\
\text { (it) }\end{array}$ & $\begin{array}{l}-0.0756^{* *} \\
(4.36)\end{array}$ & $\begin{array}{l}-0.0495 * * \\
(4.09)\end{array}$ & $\begin{array}{l}-0.0586^{* * *} \\
(7.51)\end{array}$ & \begin{tabular}{|l|}
-0.0166 \\
$(1.14)$
\end{tabular} & $\begin{array}{l}-0.0462 * * \\
(3.50)\end{array}$ & $\begin{array}{l}-0.0472 * \\
(2.49)\end{array}$ & \\
\hline Labor unit cost (it) & \begin{tabular}{|l|}
0.0043 \\
$(0.26)$ \\
\end{tabular} & $\begin{array}{l}0.0067 \\
(0.19) \\
\end{array}$ & $\begin{array}{l}-0.0068 * * \\
(3.81)\end{array}$ & $\begin{array}{l}-0.0034 * \\
(2.01)\end{array}$ & $\begin{array}{l}-0.0136 * * \\
(5.65)\end{array}$ & $\begin{array}{l}-0.0100^{*} \\
(5.51)\end{array}$ & \\
\hline $\begin{array}{l}\text { Share of small } \\
\text { business } \\
\text { employment (irt) }\end{array}$ & \begin{tabular}{|l}
$0.0207 * *$ \\
$(4.82)$
\end{tabular} & - & - & $\begin{array}{l}0.0282^{* *} \\
(5.18)\end{array}$ & - & - & \\
\hline $\begin{array}{l}\text { Minimum efficient } \\
\text { size (it) }\end{array}$ & - & $\begin{array}{l}-0.0078 * * \\
(5.71)\end{array}$ & - & - & $\begin{array}{l}-0.0279 * * \\
(7.78)\end{array}$ & - & \\
\hline $\begin{array}{l}\text { Entrepreneurial } \\
\text { technological } \\
\text { regime (irt) }\end{array}$ & - & - & $\begin{array}{l}0.0993 * * \\
(3.40)\end{array}$ & - & - & $\begin{array}{l}0.1027 \text { ** } \\
(4.37)\end{array}$ & \\
\hline $\begin{array}{l}\text { Dummies for } \\
\text { number of patents } \\
\text { per } 1,000 \\
\text { employees: }\end{array}$ & \begin{tabular}{|l}
$1.0031^{* *}$ \\
$(5.25)$ \\
$1.9035^{* *}$ \\
$(4.91)$
\end{tabular} & $\begin{array}{l}1.4830 * * \\
(7.54) \\
2.5146^{* *} \\
(5.57)\end{array}$ & $\begin{array}{l}0.9982 * * \\
(4.14) \\
0.5974 \\
(1.66)\end{array}$ & $\begin{array}{l}0.4669 \\
(1.70) \\
0.9889 * * \\
(2.90)\end{array}$ & $\begin{array}{l}0.6095 * \\
(2.21) \\
1.0571 * * \\
(2.56)\end{array}$ & $\begin{array}{l}1.2121 * * \\
(3.48) \\
2.0890^{* *} \\
(4.27)\end{array}$ & \\
\hline Patent 25-50 & $1.5887 * *$ & $4.4793 * *$ & 0.1944 & 0.3834 & 0.2233 & $3.2427 *=\mathrm{DC}$ & Deleted: Dummy \\
\hline Patent $50-75$ & $(4.53)$ & $(5.49)$ & $(0.78)$ & $(1.53)$ & $(0.26)$ & $(4.81)$ & Deleted: Dummy \\
\hline$\frac{\text { Patent }}{\text { Chi2 }}$ & $\overline{32} . \overline{7} \overline{6}^{* *}-$ & $112.49 * *$ & $19.72 * \bar{*}$ & $\overline{12 .} \overline{6} \overline{6}^{* *}$ & $2 \overline{4} . \overline{5} \overline{5}^{* *}$ & $23.69 * * D$ & Deleted: Dummy \\
\hline $\begin{array}{l}\text { Dummies for } \\
\text { planning regions } \\
\text { Chi2 }\end{array}$ & \begin{tabular}{|l|} 
Yes** \\
$(175.40)$
\end{tabular} & \begin{tabular}{|l} 
Yes** \\
$(216.38)$
\end{tabular} & $\begin{array}{l}\text { Yes** } \\
(95.00)\end{array}$ & $\begin{array}{l}\text { Yes** } \\
(156.66)\end{array}$ & $\begin{array}{l}\text { Yes** } \\
(97.89)\end{array}$ & $\begin{array}{l}\text { Yes } \\
(63.95)\end{array}$ & \\
\hline $\begin{array}{l}\text { Dummies for } \\
\text { Federal States } \\
\text { (Laender) } \\
\text { chi2 }\end{array}$ & \begin{tabular}{|l|} 
Yes*** \\
$(27.16)$
\end{tabular} & \begin{tabular}{|l} 
Yes** \\
$(94.37)$
\end{tabular} & $\begin{array}{l}\text { Yes* } \\
(14.21)\end{array}$ & $\begin{array}{l}\text { Yes*** } \\
(38.58)\end{array}$ & $\begin{array}{l}\text { Yes** } \\
(24.06)\end{array}$ & $\begin{array}{l}\text { Yes* } \\
(17.30)\end{array}$ & \\
\hline $\begin{array}{l}\text { Number of } \\
\text { observations }\end{array}$ & \begin{tabular}{|l|}
35,682 \\
$(12,194$ zero \\
obs. $)$
\end{tabular} & \begin{tabular}{|l}
35,682 \\
$(12,194$ zero \\
obs.)
\end{tabular} & $\begin{array}{l}35,682 \\
(12,194 \text { zero } \\
\text { obs. })\end{array}$ & \begin{tabular}{|l}
12,432 \\
$(1,250$ zero \\
obs. $)$
\end{tabular} & $\begin{array}{l}12,432 \\
(1,250 \text { zero } \\
\text { obs. })\end{array}$ & $\begin{array}{l}12,432 \\
(1,250 \text { zero } \\
\text { obs. })\end{array}$ & \\
\hline Wald chi2 (26) & $2,809.81 * *$ & $2,697.35^{* *}$ & $1,459.52 * *$ & $3,556.28 * *$ & $6,490.19 * *$ & $3,310.36^{* *}$ & \\
\hline Mc Fadden's R ${ }^{2}$ & 0.150 & 0.193 & 0.133 & 0.132 & 0.150 & 0.097 & \\
\hline $\mathrm{ML} \mathrm{R}^{2}$ & 0.562 & 0.635 & 0.505 & 0.770 & 0.808 & 0.660 & \\
\hline $\begin{array}{l}\text { Cragg \& Uhler's } \\
\mathrm{R}^{2}\end{array}$ & 0.564 & 0.638 & 0.507 & 0.770 & 0.808 & 0.660 & \\
\hline
\end{tabular}

Zero inflated negbin model with standard errors adjusted for clustering; i: industry, r: region, $\mathrm{t}$ : time. Absolute z-statistics in parentheses; **: statistically significant at the 1 percent level, *: statistically significant at the 5 percent level. 
Figure 1: Number of start-ups in West Germany per year between1983 and

1997

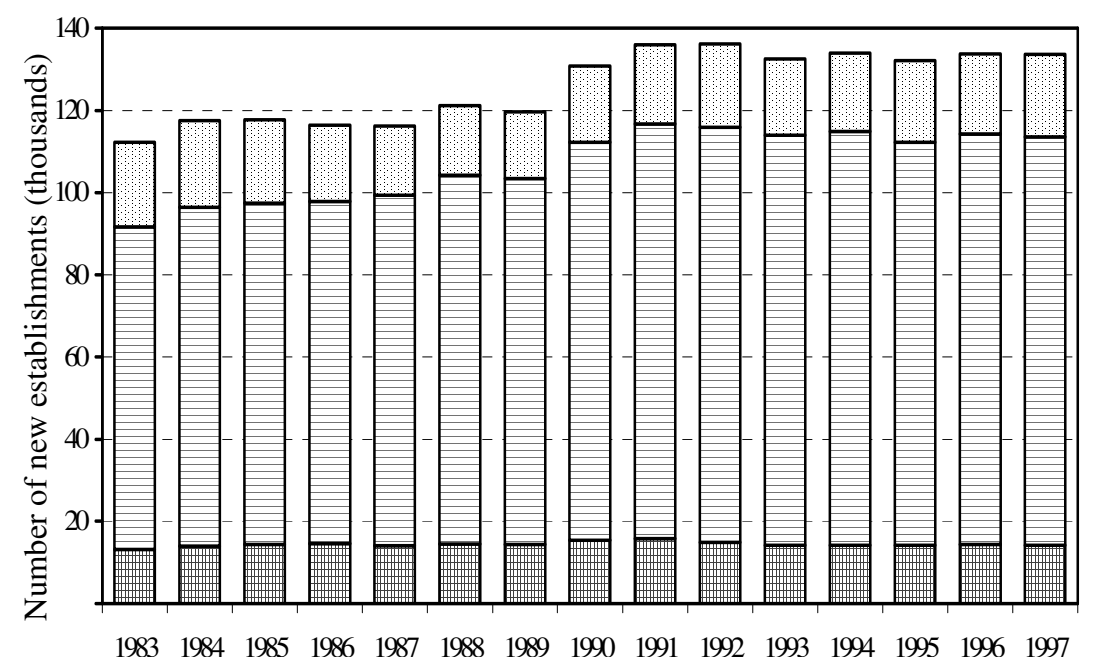

TManufacturing $\boxminus$ Services GOher private sectors 


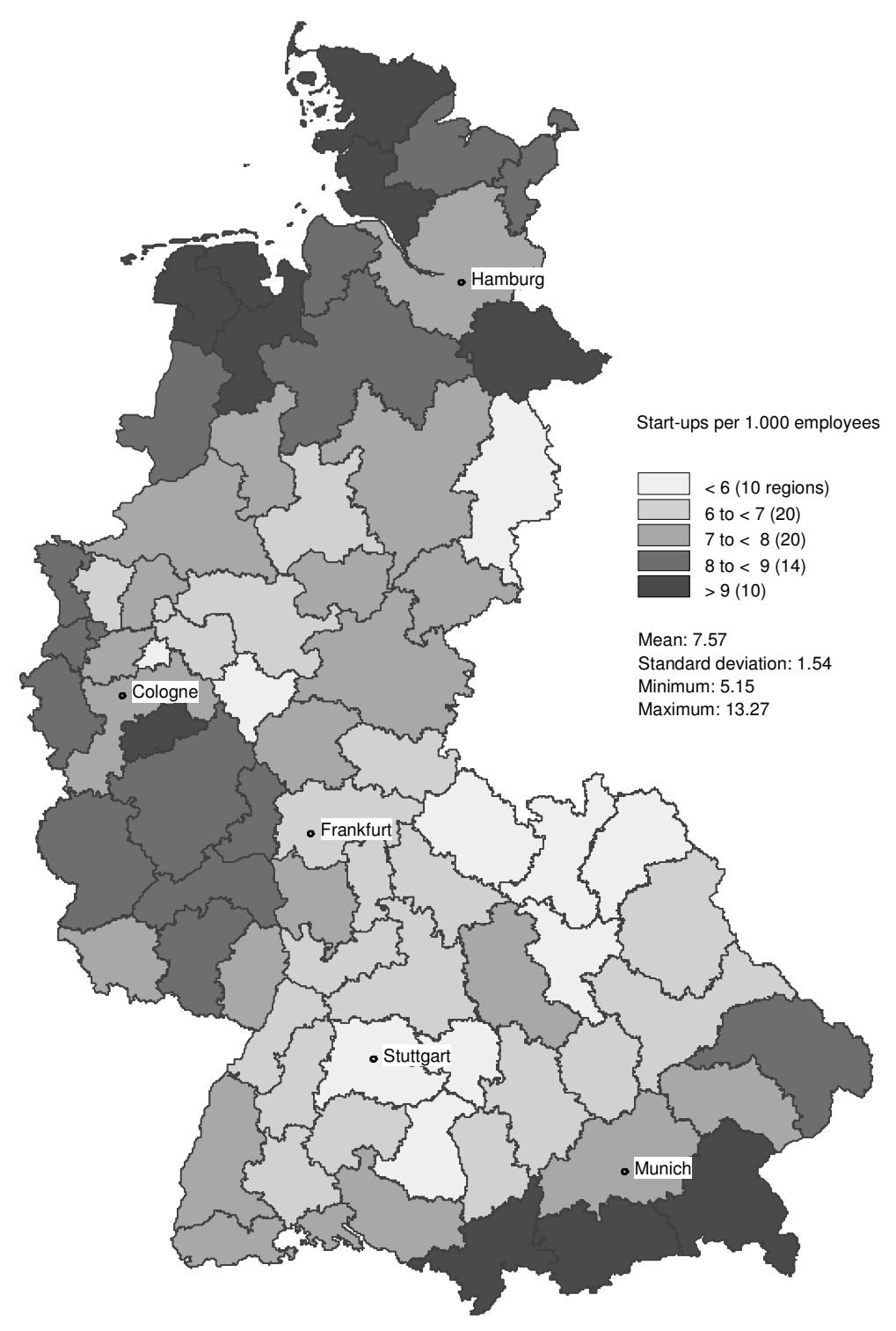

Figure 2: Average start-up rates (start-ups per 1,000 employees) for all private sector industries in West German regions from 1983 to1997 
Notes

* The research reported here is based on the project "Gründungsdaten und Analysen des Gründungsgeschehens" (Data on New Firms and Analyses of New Firm Formation) funded by the German Science Foundation. Comments by Olav Sorenson, Joachim Wagner, and three anonymous referees on earlier versions helped us to improve the paper.

${ }^{1}$ In this paper, we use the term "new business" as the overall category for both new firm headquarters and new subsidiaries. Our empirical data include these two categories of new entities.

${ }^{3}$ For an overview of cross-sectional studies of industries see EVANS and SIEGFRIED (1994) and GEROSKI (1995). The evidence of interregional analyses is summarized in REYNOLDS et al. (1994).

${ }^{4}$ The only longitudinal analyses of new firm formation that we are aware of are KEEBLE, WALKER, and RoBSON (1993), JOHNSON and PARKER (1996), SUTARIA (2001) as well as SUTARIA and HICKS (2004).

${ }^{5}$ AUDRETSCH and FRITSCH (1999) provide some empirical evidence on the industry component of regional new business formation processes.

${ }^{6}$ Individual characteristics which may be conducive to starting a business are an entrepreneurial attitude (the pursuit of economic success, independence, self-realization, and the capability to bear risk), an appropriate qualification (expertise, management abilities) as well as the opportunity costs of becoming an entrepreneur, such as the income and the career prospects provided by the current position (c.f. CHELL et al., 1991).

${ }^{7}$ WAGNER (2004) found that the propensity to be a nascent entrepreneur is particularly pronounced for employees working in firms which are both small and young. According to MUELLER (2005), work experience in a small firm as well as an entrepreneurial environment has a positive impact on the propensity of someone to be a nascent entrepreneur. 


\footnotetext{
8 “"Through direct contact with successful entrepreneurs, people gain opportunities to gather more information about transition from worker to entrepreneur and to conduct a more accurate personal assessment of their ability to succeed" (SORENSON and AUDIA, 2000, p. 443).

${ }^{9}$ Cf. ReYNOLdS et al. (1994), Fotopoulos and SPENCE (1999), ARmington and ACs (2002).

${ }^{10}$ SORENSON and STUART (2001) show that spatial proximity between actors may be important for establishing and maintaining a venture-capital relationship. Accordingly, venture capital is not evenly available in all regions.

${ }^{11}$ The share of new establishments in the data with more than 20 employees in the first year is rather small (about 2.5 percent). Applying a definition without a size-limit does not lead to any significant changes of the results.
}

12 The definition of the planning regions developed in the 1980s was used for the whole period for reasons of consistency. For this definition of the planning regions see BUNDESFORSCHUNGSANSTALT FÜR LANDESKUNDE UND RAUMORDNUNG (1987, 7-10). The Berlin region was excluded due to changes in the definition of the region in the time period under investigation. One might suppose that the German unification in 1990 would have had an effect on start-up activity in regions along the former border with East Germany. However, a close inspection shows that such effects, if they exist at all, tend to be rather small and are, in any case, not significant enough to justify the exclusion of these regions.

13 The "other private sectors" are agriculture and forestry, fishery, energy, water supply, mining, and construction.

14 Due to the fact that industries and regions differ considerably in their economic potential, the absolute number of new businesses may not be a meaningful indicator for comparisons of new business formation processes. To account for such differences in economic potential, it is a common practice to analyze start-up rates that relate the number of new businesses to an indicator 
for the economic potential of the respective region. To the degree that new businesses are set up in the industry in which the founder is employed and are located near the founder's residence, the number of employees in an industry and region can be regarded as a measure of the number of potential entrepreneurs. In this case, the start-up rate represents the probability that an employee in a given industry and region will set up a new business during the given period of time (cf. AUDRETSCH and FRITSCH, 1994). This interpretation neglects start-ups by unemployed persons. However, there is no plausible way to allocate the unemployed persons to the different industries since information about place of former employment was not available.

15 For a more detailed description of the estimation method see GOLDSTEIN (1995), BRYK and RAUDENBUSH (1992) as well as SNIJDERS and BOSKER (1999).

${ }^{16}$ The analysis by SUTARIA (2001) and SUTARIA and HICKS (2004) is an example of such a pseudo-correlation when taking start-up rates as the dependent variable. The authors find a positive effect of mean establishment size (mean number of employees per establishment) and the start-up rate, which is defined as the number of new businesses over the number of incumbents. However, if the mean establishment size is relatively high, it causes the number of establishments - the denominator of the start-up rate - to be relatively small, thus, leading to a high value of the start-up rate.

${ }^{17}$ Missing values may occur with regard to the share of small business employment or the entrepreneurial character of the technological regime if there is no employee or no R\&D employee present in an industry and region. In our sample, this refers to 1.4 percent of all observations

${ }^{18}$ WILLIAMS (2000) presents a general proof that this estimator is unbiased for clustercorrelated data regardless of the setting.

${ }^{19}$ Taking the 75th percentile of establishment size is, of course, an arbitrary choice. However, our analyses showed that we get quite similar results for this variable if we chose other percentiles of the size distribution such as the median. 
43

${ }^{20}$ This is indicated by the higher $\mathrm{t}$-values of the minimum efficient size indicator as well as by, the in most cases, higher values of the $\mathrm{R}^{2}$ in the models containing minimum efficient size instead of small business presence.

${ }^{21}$ There is also considerable correlation between the qualification variables and other size related variables such as the share of small business employees and the indicator for minimum efficient size. The reason is that academic qualifications are mainly found in larger firms, not in small ones.

22 Obviously, this effect is mainly limited to changes in the preceding year because estimate lags for more remote time periods were not found to be statistically significant. 